\title{
Pengaruh Earning per Share, Debt to Equity Ratio, Suku Bunga dan Inflasi terhadap Price to Book Value pada Perbankan di Bursa Efek Indonesia
}

\author{
Silvi Reni Cusyana ${ }^{1}$, Suyanto ${ }^{2}$
}

${ }^{1}$ Universitas Pancasila, Jl. Srengseng Sawah, Jagakarsa, Jakarta Selatan 12640

${ }^{2}$ Sekolah Tinggi Ilmu Ekonomi IPWI Jakarta, Jl. Letda Natsir No.7 Nagrak, Gn. Putri Cibubur, Bogor

I N F O A R T I KEL

\author{
JEL Classification: \\ $H 83$ \\ M12
}

\section{Keywords:}

earning per share, debt to equity ratio, interest rates, inflation and price to book value.

\section{$A B S T R A C T$}

The research objective is to prove and explain the effect of earnings per share, debt to equity ratio, interest rates and inflation on the price to book value (corporate banking in Indonesia in 20072012. The sampling technique in this research is purposive sampling. The data required in research this is obtained of Indonesian Capital Market Directory (ICMD), Indonesia Stock Exchange (IDX) and Bank Indonesia (BI). the method of data analysis used is multiple linear regression. the study concluded that there is influence of earning per share, debt to equity ratio, interest interest and inflation to price to book value in banking in Indonesia Stock Exchange.

\section{A B S T R A K}

Tujuan penelitian adalah membuktikan dan menjelaskan pengaruh earning per share, debt to equity ratio, suku bunga dan inflasi terhadap price to book value (perusahaan perbankan di Indonesia tahun 2007-2012. Teknik pengambilan sampel dalam penelitian ini adalah purposive sampling. Data yang diperlukan dalam penelitian ini diperoleh dari Indonesian Capital Market Directory (ICMD), Bursa Efek Indonesia (BEI) dan Bank Indonesia (BI). Metode analisis data yang digunakan adalah regresi linear berganda. Hasil penelitian menyimpulkan bahwa ada pengaruh Earning per Share, Debt to Equity Ratio, Suku Bunga dan Inflasi terhadap Price to Book Value pada Perbankan di Bursa Efek Indonesia.

\section{Pendahuluan}

Para investor sebelum melakukan investasi perlu mengetahui dan memilih saham-saham yang dapat memberikan keuntungan paling optimal bagi dana yang diinvestasikannya. Semakin banyak investor yang ingin menginvestasikan suatu saham, harganya cenderung naik, sebaliknya semakin banyak investor yang ingin menjual atau melepaskan suatu saham, harganya cenderung bergerak turun. Harga saham di masa yang akan datang dapat di estimasi melalui faktor-faktor fundamental dan teknikal yang mempengaruhi harga saham. Salah satu pendekatan dalam menentukan penilaian saham adalah dengan melihat price to book value (PBV). Bila suatu perusahaan mempunyai PBV di atas $1(>1)$, maka harga saham perusahaan tersebut dinilai 
lebih tinggi dari pada nilai bukunya yang menggambarkan kinerja perusahaan tersebut semakin baik dimata investor (Marfuatun dan Indarti, 2012; ).

Putra (2007; Safitri, 2013) menunjukkan bukti empiris bahwa data Earning Per Share dan Debt to Equity Ratio signifikan berpengaruh terhadap Price to Book Value, namun Return On Assets, Beta Saham dan Divident Payout Ratio tidak berpengaruh signifikan terhadap Price to Book Value. Secara individual, debt to equity ratio dan divident payout ratio berhubungan negatif dan tidak signifikan dengan price to book value sedangkan return on equity dan size berhubungan positif dan signifikan terhadap price to book value.

Wardjono (2010) membuktikan bahwa Return on Equity (ROE) dan Growth berpengaruh signifikan terhadap Price to Book Value (PBV), sementara pengujian pada Dividend Payout Ratio (DPR) dan Degree of Financial Leverage tidak berpengaruh signifikan terhadap Price to Book Value (PBV). Hasil penelitian ini menunjukkan bahwa profitabilitas dan tingkat pertumbuhan merupakan faktor yang dipertimbangkan oleh investor. Semakin tinggi Price to Book Value (PBV), semakin baik pasar memandang perusahaan dan prospeknya, hal ini berarti semakin berhasil perusahaan menciptakan nilai bagi pemegang saham. Perusahaan yang dipandang baik oleh investor adalah perusahaan dengan laba dan arus kas yang aman serta terus menerus mengalami pertumbuhan. Price to Book Value (PBV) diperoleh dari harga pasar per lembar saham dibagi dengan nilai buku per lembar saham yaitu jumlah ekuitas dibagi dengan jumlah saham yang beredar. Untuk menciptakan nilai pasar yang tinggi banyak faktor yang harus diperhatikan. Salah satu faktor yang menjadi penilaian adalah kinerja dari perusahaan.

Adanya kenaikan Earning per Share (EPS) menunjukkan adanya kenaikan laba dari perusahaan. Earning per Share (EPS) merupakan besarnya laba yang diperoleh perusahaan dibagi dengan jumlah saham yang beredar dan kenaikan Earning Per Share (EPS) seharusnya diikuti dengan perubahan kenaikan Price to Book Value (PBV) yang searah. Earning Per Share (EPS) dihitung dari Net Income dibagi dengan share outstanding (jumlah saham yang beredar) Ross (2010). Indikator lainnya yang mempengaruhi price to book value adalah debt to equity ratio (DER). Debt to Equity Ratio merupakan rasio solvabilitas yang mengukur kemampuan kinerja perusahaan dalam mengembalikan hutang jangka panjangnya dengan melihat perbandingan antara total hutang dengan total ekuitasnya. Adapun faktor-faktor teknikal yang mempengaruhi price to book value adalah suku bunga dan inflasi.

Umumnya tingkat suku bunga mempunyai hubungan negatif dengan bursa saham dan apabila pemerintah mengumumkan tingkat suku bunga akan naik, maka investor akan menjual sahamnya dan menggantikannya dengan instrumen berpendapatan tetap (fixed income securities) yang memberikan tingkat suku bunga yang tinggi. Adanya kenaikan tingkat suku bunga seharusnya diikuti dengan perubahan penurunan Price to Book Value (PBV) yang searah, namun pada kenyataannya tidak sesuai dengan perubahan Price to Book Value (PBV). Tingginya inflasi menunjukkan bahwa risiko untuk melakukan investasi cukup besar sebab inflasi yang tinggi akan mengurangi return dari investor. Pada kondisi inflasi yang tinggi maka harga barang-barang cenderung untuk meningkat. Peningkatan harga barang-barang dan bahan baku akan membuat biaya produksi menjadi tinggi sehingga akan berpengaruh pada penurunan jumlah permintaan yang berakibat pada penurunan penjualan, sehingga hal ini mengurangi pendapatan yang diperoleh investor dari investasinya, setiap terjadi penurunan tingkat inflasi maka harga saham akan meningkat.

Hipotesis penelitian merupakan dugaan sementara sebelum dilakukannya penelitian dalam hal pendugaannya menggunakan statistika untuk mengalisisnya. Berdasarkan pengertian tersebut, disimpulkan bahwa hipotesis penelitian dapat diartikan sebagai jawaban yang bersifat sementara dari obyek penelitian, hingga terbukti melalui data yang terkumpul dan diuji secara empiris.

\section{Telaah Teori dan Pengembangan Hipotesis}

\subsection{Signaling Theory}

Signaling theory menurut Brigham (2011) adalah suatu tindakan yang diambil manajemen suatu perusahaan yang memberi petunjuk bagi investor tentang bagaimana manajemen memandang prospek perusahaan. Perusahaan dengan prospek yang 
menguntungkan akan mencoba menghindari penjualan saham dan mengusahakan setiap modal baru yang diperlukan dengan cara-cara lain, termasuk penggunaan hutang. Teori sinyal menunjukkan adanya asimetri informasi antara manajemen perusahaan dan pihak-pihak yang berkepentingan dengan informasi tersebut. Informasi merupakan unsur penting bagi investor dan pelaku bisnis karena informasi pada hakekatnya menyajikan keterangan, catatan atau gambaran baik untuk keadaan masa lalu, saat ini maupun keadaan masa yang akan datang bagi kelangsungan hidup suatu perusahaan dan bagaimana pasaran efeknya. Informasi yang lengkap, relevan, akurat dan tepat waktu sangat diperlukan oleh investor di pasar modal sebagai alat analisis untuk mengambil keputusan investasi.

Miller dan Rock (1985) berasumsi bahwa setiap orang, baik investor maupun manajer memiliki informasi yang sama tentang prospek suatu perusahaan. Hal ini disebut sebagai informasi simetris (symmetric information), namun pada kenyataannya manajer sering kali memiliki informasi yang lebih baik dibandingkan investor luar. Hal ini disebut informasi asimetri (asymetric information)

Pengumuman emisi suatu saham oleh suatu perusahaan merupakan suatu isyarat (signal) bahwa manajemen memandang prospek perusahaan kurang cerah. Apabila suatu perusahaan menawarkan penjualan saham baru, maka harga sahamnya kemungkinan akan menurun, karena menerbitkan saham baru berarti memberikan isyarat negatif yang kemudian dapat menekan harga saham sekalipun prospek perusahaan cerah.

\subsection{Pengertian Price Book Value (PBV)}

Salah satu rasio pasar adalah price to book value. Price to book value merupakan rasio yang digunakan untuk mengukur kinerja harga saham terhadap nilai bukunya (Ang, 1997). Perusahaan yang baik umumnya rasio PBV nya di atas satu, yang menunjukkan bahwa nilai pasar saham lebih besar dari pada nilai bukunya, semakin besar rasio PBV,semakin tinggi investor menilai perusahaan, sehingga akan semakin besar peluang membeli saham perusahaan. Semakin tinggi rasio ini berarti pasar percaya akan prospek perusahaan tersebut.

Price to book value dapat dihitung dengan menggunakan rumus :

$$
\mathrm{PBV}=\frac{\text { Harga Pasar Saham }}{\text { Nilai buku perlembar saham }}
$$

Nilai buku per lembar saham menunjukkan aktiva bersih yang dimiliki oleh pemegang saham dengan memiliki satu lembar saham (Jogiyanto, 1998 : 63). Adanya asumsi aktiva bersih saham dengan total ekuitas pemegang saham, maka nilai buku per lembar saham adalah total ekuitas dibagi dengan jumlah saham yang beredar, sehingga nilai buku per lembar saham dapat dirumuskan sebagai berikut :

Nilai buku

Total ekuitas

per lembar saham $=$

Jumlah saham yang beredar

Semakin tinggi nilai rasio PBV semakin tinggi penilaian investor dibandingkan dengan dana yang ditanamkan dalam perusahaan tersebut, sehingga semakin besar pula peluang para investor untuk membeli saham perusahaan. Keberhasilan perusahaan menciptakan nilai tersebut tentunya memberikan harapan kepada pemegang saham berupa keuntungan yang lebih besar pula (Sartono, 2001). Nilai perusahaan merupakan persepsi investor terhadap tingkat keberhasilan perusahaan dalam mengelola sumber daya pada akhir tahun berjalan yang tercermin pada harga saham perusahaan. Jadi harga saham merupakan cerminan nilai suatu perusahaan.

Semakin tinggi harga saham semakin tinggi pula nilai perusahaan, sebaliknya semakin rendah harga saham maka nilai perusahaan juga rendah atau kinerja perusahaan kurang baik. Nilai perusahaan diukur dengan price to book value (PBV) yaitu rasio yang mengukur nilai perusahaan dengan membandingkan harga saham per lembar saham. PBV mempunyai 2 fungsi utama (Dev Group on research, 2009), yaitu:

1. Untuk melihat apakah sebuah saham saat ini diperdagangkan pada harga yang mahal, masih murah, atau masih wajar menurut rata-rata historisnya.

2. Untuk menentukan mahal atau murahnya suatu saham saat ini yang didasarkan perkiraan harga wajar untuk periode 1 tahun mendatang. 
Menurut Wardjono (2010) investor dapat mempertimbangkan rasio pasar modal seperti rasio harga terhadap nilai bukunya (Price to Book Value) yang selanjutnya disingkat PBV, untuk menentukan saham mana yang harganya wajar, terlalu tinggi (overvalued), atau terlalu rendah (undervalued). Rasio harga pasar suatu saham terhadap nilai bukunya memberikan indikasi pandangan investor atas perusahaan. Rasio ini mengukur nilai yang diberikan pasar keuangan kepada manajemen dan organisasi sebagai perusahaan yang terus tumbuh. Semakin tinggi rasio Price to Book Value, semakin berhasil perusahaan menciptakan nilai bagi pemegang saham.

\subsection{Earning per Share (EPS)}

Earning per Share (EPS) merupakan ukuran penting yang digunakan untuk mengukur kinerja perusahaan. Earning Per Share (EPS) adalah keuntungan perusahaan yang bisa dibagikan kepada pemegang saham. Tapi dalam prakteknya, tidak semua keuntungan ini dapat dibagikan, ada sebagian yang ditahan sebagai laba ditahan. Menurut Ang (1997), Earning Per Share (EPS) merupakan perbandingan antara laba bersih setelah pajak pada satu tahun buku dengan jumlah saham yang diterbitkan.

Salah satu indikator keberhasilan suatu perusahaan ditunjukkan oleh besarnya tingkat keuntungan atas per lembar saham. Pada umumnya para investor akan mengharapkan manfaat dari investasinya dalam bentuk laba per lembar saham (EPS). Hal ini disebabkan EPS dapat menggambarkan jumlah keuntungan yang diperoleh untuk setiap lembar saham biasa. Sedangkan jumlah EPS yang bakal didistribusikan kepada investor saham tergantung pada kebijakan perusahaan dalam hal pembayaran deviden. Adapun EPS yang tinggi menandakan bahwa perusahaan tersebut mampu memberikan tingkat kesejahteraan yang lebih baik pada pemegang saham. Sebaliknya EPS yang rendah menandakan bahwa perusahaan telah gagal memberikan kemanfaatan sebagaimana yang diharapkan oleh pemegang saham. Oleh sebab itu, perusahaan yang stabil akan memperlihatkan stabilitas pertumbuhan EPS, sebaliknya perusahaan yang tidak stabil akan memperlihatkan pertumbuhan yang fluktuatif. Secara sistematis Earning Per Share (EPS) dapat dirumuskan sebagai berikut.
EPS $=\underline{\text { Laba Bersih Setelah Bunga dan Pajak }}$

\author{
Jumlah Saham Beredar
}

Putra (2007) dalam penelitiannya menunjukkan hasil bahwa variabel Earning Per Share (EPS) memiliki pengaruh yang signifikan terhadap Price to Book Value. Arah koefisien positif menunjukkan bahwa peningkatan Earning Per Share (EPS) akan meningkatkan Price to Book Value. Hasil penelitian ini mengindikasikan bahwa Earning Per Share yang naik mencerminkan hasil investasi per lembar saham meningkat, sehingga kepercayaan investor meningkat dan harga saham juga meningkat. Dampak akhirnya adalah Price to Book Value juga meningkat. Makin tinggi Earning Per Share menunjukkan makin tinggi laba yang diperoleh perusahaan. Ketika investor mengevaluasi performance dari perusahaan, investor tidak cukup hanya mengetahui apakah income suatu perusahaan mengalami kenaikan atau penurunan, investor juga perlu mencermati bagaimana perubahan income berakibat terhadap investasinya. Perusahaan yang mapan umumnya mempunyai rasio Earning Per Share tinggi, sedangkan perusahaan yang berusia muda mempunyai kecenderungan Earning Per Share (EPS) yang rendah. Dengan demikian Earning Per Share (EPS) berpengaruh positif terhadap Price to Book Value (PBV).

\subsection{Debt to Equity Ratio (DER)}

Suatu perusahaan didirikan tentunya dengan tujuan memaksimalisasi harga saham dan pencapaian profitabilitas. Untuk mencapai tujuan tersebut dibutuhkan modal, baik modal sendiri dari intern perusahaan yakni dengan mengeluarkan saham maupun modal dari ekstern berupa hutang. Struktur modal diukur dengan leverage yakni ukuran yang digunakan untuk menggambarkan kemampuan perusahaan yang menggunakan aktiva atau dana yang mempunyai beban tetap untuk memperbesar tingkat pengembalian atau laba bersih bagi pemilik perusahaan. Menurut Harahap (2002) "Perusahaan yang baik mestinya memiliki komposisi modal yang lebih besar dari utang". Sedangkan menurut Sartono (2001), "rasio leverage adalah rasio yang mengukur seberapa besar perusahaan dibiayai dengan utang".

Menurut Harahap (2002) perusahaan yang baik mestinya memiliki komposisi modal 
yang lebih besar dari utang. Sedangkan menurut Sartono (2001) rasio leverage adalah rasio yang mengukur seberapa besar perusahaan dibiayai dengan utang. Husnan (2002) leverage financial menyangkut penggunaan dana yang diperoleh pada biaya tetap tertentu dengan harapan bisa meningkatkan bagian pemilik modal sendiri. Financial leverage yang akan digunakan dalam penelitian ini adalah debt to equity ratio (DER), merupakan perbandingan antara total hutang terhadap total ekuitas yang dimiliki perusahaan. Total hutang di sini merupakan total hutang jangka pendek dan total hutang jangka panjang, sedangkan total ekuitas adalah total modal sendiri (total modal saham disetor dan laba ditahan) yang dimiliki oleh perusahaan, dapat diukur dengan rumus sebagai berikut :

\section{DER $=\quad$ Total Hutang Total Ekuitas}

\section{Purwanto dan Haryanto} menyatakan bahwa semakin besar debt to equity ratio suatu perusahaan menunjukkan risiko distribusi laba usaha perusahaan akan semakin besar terserap untuk melunasi kewajiban perusahaan. Ariadi (2009) menyebutkan bahwa rasio hutang terhadap ekuitas (DER) memiliki pengaruh negatif dan signifukan terhadap return saham. demikian juga Sulistio (2005) mengatakan bahwa ukuran perusahaan (size), Earning Per Share (EPS), Price Earning Ratio (PER) dan tingkat leverage, menunjukkan pengaruh negatif signifikan terhadap initial return. Hidayati (2010) dan Putra (2007) yang menemukan bahwa debt to equity ratio berpengaruh negatif dan tidak signifikan terhadap price to book value perusahaan. Makin tinggi tingkat leverage akan semakin tinggi resiko perusahaan yang pada akhirnya akan menurunkan harga saham. Turunnya harga saham dapat mengakibatkan turunnya price to book value. Dengan demikian, debt to equity ratio berpengaruh negatif terhadap price to book value.

\subsection{Suku Bunga}

Tingkat suku bunga atau interest rate merupakan rasio pengembalian sejumlah investasi sebagai bentuk imbalan yang diberikan investor, besarnya tingkat suku bunga bervariatif sesuai dengan kemampuan debitur dalam memberikan tingkat pengembalian kepada kreditur. Tingkat suku bunga tersebut dapat menjadi salah satu pedoman investor dalam pengambilan keputusan investasi pada pasar modal. Dengan membandingkan tingkat keuntungan dan resiko pada pasar modal dengan tingkat suku bunga yang ditawarkan sektor keuangan, investor dapat memutuskan bentuk investasi yang mampu menghasilkan keuntungan yang optimal. Tingkat suku bunga sektor keuangan yang lazim digunakan sebagai panduan investor disebut juga tingkat suku bunga bebas resiko (risk free), yaitu meliputi tingkat suku bunga bank sentral dan tingkat suku bunga deposito. Menurut Manurung, dkk. (2005) "Tingkat bunga merupakan pengembalian asset yang mempunyai resiko dekat dengan nol“". Umumnya tingkat bunga ini mempunyai hubungan negatif dengan bursa saham dan apabila pemerintah mengumumkan tingkat bunga akan naik, maka investor akan menjual sahamnya dan menggantikannya dengan instrumen berpendapatan tetap (fixed income securities) yang memberikan tingkat suku bunga yang tinggi.

\subsection{Inflasi}

Menurut Herman (2003) menyatakan bahwa "Inflasi adalah suatu keadaan yang ditandai dengan peningkatan harga-harga pada umumnya atau turunnya nilai mata uang yang beredar". Menurut Ratih (2006 : 35) menyatakan bahwa "inflasi adalah suatu keadaan dalam perekonomian dimana terjadi kenaikan harga-harga secara umum". Kenaikan dalam harga barang dan jasa yang biasa terjadi jika permintaan". Inflasi adalah ketika harga melambung karena terlalu banyak uang dalam peredaran, dan tidak cukupnya barang dan jasa untuk dibelanjakan, maka terjadilah inflasi. Bila harga kian naik melampaui kemampuan orang untuk membayar, maka permintaan menurun dan kelesuan ekonomi mulai berlangsung". Dibawah ini adalah faktor-faktor penyebab inflasi menurut Arifin (2004:12), yaitu :

1. Inflasi disebabkan oleh sektor ekspor impor, jika ekspor suatu negara lebih besar dari pada impor, akan mengakibatkan terjadinya tekanan inflasi, tekanan inflasi terjadi karena semakin besar jumlah uang yang beredar di dalam negeri akibat permintaan devisa.

2. Inflasi disebabkan oleh sektor penerimaan dan pengeluaran negara. Sektor penerimaan dan pengeluaran negara yang defisit menjadi penyebab inflasi. Karena 
pengeluaran pemerintah lebih besar dari pada penerimaanya, maka untuk menutupi keadaan tersebut akan dilakukan dengan mengeluarkan uang baru, pengeluaran baru menimbulkan tekanan inflasi.

3. Inflasi disebabkan oleh sektor swasta pengeluaran kredit dalam jumlah yang cukup besar untuk memenuhi permintaan kredit swasta dapat juga menyebabkan terjadinya inflasi.

Dari penyebab inflasi di atas dapat disimpulkan bahwa pengendalian jumlah uang yang beredar di masyarakat dan keseimbangan antara permintaan dan penawaran barang merupakan salah satu hal yang dapat dilakukan untuk menekan inflasi.

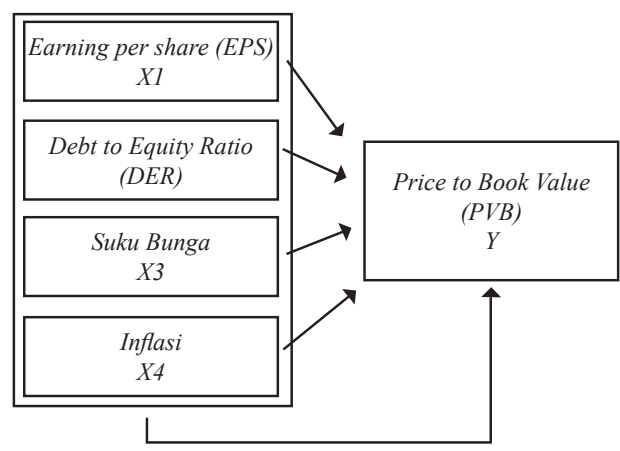

Gambar 1.

Kerangka Pemikiran

Berdasarkan rerangka pemikiran dan uraian di atas, maka diambil hipotesis sebagai berikut :

1. H1: Earning Per Share berpengaruh secara signifikan terhadap Price to Book Value.

2. H2: Debt to Equity Ratio berpengaruh secara signifikan terhadap Price to Book Value.

3. H3: Suku bunga berpengaruh secara signifikan terhadap Price to Book Value.
4. H4: Inflasi berpengaruh secara signifikan terhadap Price to Book Value.

\section{Metode Penelitian}

Penelitian ini dilakukan untuk membuktikan dan menjelaskan sejauh mana pengaruh variabel earning per share, debt to equity ratio, suku bunga dan inflasi terhadap price to book value. Menurut Sugiyono (2010:215), sampel adalah sebagian dari populasi itu. Populasi itu misalnya penduduk di wilayah tertentu, jumlah pegawai pada organisasi tertentu, jumlah guru dan murid di sekolah tertentu dan sebagainya.

Penelitian ini dilakukan dengan menggunakan data keuntungan obyek penelitian (populasi) adalah perbankan di Bursa Efek Indonesia yang telah mempublikasikan laporan keuangan tahunannya untuk periode enam tahun yaitu dari 2007 sampai dengan tahun 2012. Alasan digunakannya data mulai dari tahun 2007 adalah karena adanya pergerakan fluktuatif pada price to book value, dan data yang digunakan adalah laporan keuangan enam tahun yang terakhir. Sedangkan Kriteria yang digunakan untuk penentuan sampel dalam penelitian ini adalah:

1. Perbankan yang tercatat di Bursa Efek Indonesia selama periode tahun 2007-2012.

2. Perbankan yang menerbitkan laporan keuangan untuk periode tahun 20072012 dan memiliki kelengkapan data yang diperlukan selama berlangsungnya penelitian.

3. Perbankan yang memenuhi kriteria kemudian dihitung : Earning Per Share, Debt to Equity Ratio, Suku Bunga, Inflasi dan Price to Book Value selama periode penelitian.

Tabel 2.

Jumlah Sampel Berdasarkan Kriteria

\begin{tabular}{|c|c|c|}
\hline No. & Kriteria Sampel & Jumlah \\
\hline 1 & Perbankan yang terdaftar di BEI berturut-turut mulai tahun 2007-2012 & 31 \\
\hline 2 & $\begin{array}{l}\text { Perbankan yang tidak secara berturut-turut mempublikasikan laporan keuangan mulai } \\
\text { tahun 2007-2012 }\end{array}$ & 11 \\
\hline 3 & $\begin{array}{l}\text { Jumlah sampel tahun 2007-2012 } \\
\text { ( } 20 \text { sampel bank x } 6 \text { tahun ) }\end{array}$ & 120 \\
\hline 4 & Data outlier setelah di lakukan penelitian & $(19)$ \\
\hline 5 & Data perbankan yang di teliti tahun $2007-2012$ & 101 \\
\hline
\end{tabular}


Data yang digunakan dalam penelitian ini merupakan data sekunder dimana metode pengumpulan data yang digunakan adalah dengan strategi langsung dan dengan mencatat atau mendokumentasikan data, teknik ini digunakanuntuk datalapangandan pengumpulan data dan basis data yang pada laporan keuangan pemahaman dan yang dipublikasikan oleh Indonesian Capital Market Directory (ICMD) ataupun Bursa Efek Indonesia (BEI). Analisis data penelitian ini adalah analisis kuantitatif. Teknik analisis statistik dalam penelitian ini menggunakan regresi linier berganda (multiple linear regression). Sebelum melakukan analisis regresi linier berganda terlebih dahulu dilakukan uji statistik deskripsi dan uji asumsi klasik.

Uji statistik deskriptif digunakan untuk mendeskripsikan secara ringkas variabelvariabel dalam penelitian ini. Analisis deskripsi dilakukan untuk mengetahui gambaran atau deskripsi suatu data yang akan dianalisis. Ghozali (2012) menyebutkan bahwa statistik deskriptif memberikan gambaran atau deskripsi suatu data yang dilihat dari nilai rata-rata (mean), standar deviasi, varian, maksimum, minimum, sum, range, kurtosis dan skewness (kemenangan distribusi). Statistik deskriptif menyaikan ukuran-ukuran numerik yang sangat penting bagi data sampel. Ukuran numerik ini merupakan bentuk penyederhanaan data ke dalam bentuk yang lebih ringkas dan sederhana yang pada akhirnya mengarah pada suatu penjelasan dan penafsiran. Penelitian ini menggunakan analisis regresi berganda. Analisis ini digunakan untuk mengukur kekuatan dua variabel atau lebih dan juga menunjukkan arah hubungan antara variabel terikat dengan variabel independen. Adapun rumus dari regresi linier berganda (multiple linier regesion) adalah sebagai berikut :

$$
\begin{aligned}
& \mathrm{Y}=\mathrm{a}+\mathrm{b} 1 \mathrm{X} 1+\mathrm{b} 2 \mathrm{X} 2+\mathrm{b} 3 \mathrm{X} 3+\mathrm{b} 4 \mathrm{X} 4+\mathrm{e} . \\
& \text { Dimana } \\
& \mathrm{Y}=\text { Price to Book Value } \\
& \mathrm{X} 1=\text { Earning Per Share } \\
& \mathrm{X} 2=\text { Debt to Equity Ratio } \\
& \mathrm{X} 3=\text { Suku Bunga } \\
& \mathrm{X} 4=\text { Inflasi } \\
& \mathrm{a} \quad=\text { Konstanta } \\
& \mathrm{b} 1, \mathrm{~b} 2= \text { Koefisien regresi dari setiap variabel } \\
& \text { independen } \\
& \mathrm{e} \quad= \text { Faktor kesalahan }
\end{aligned}
$$

Nilai koefisien regresi di sini sangat menentukan sebagai dasar analisis, mengingat penelitian ini bersifat fundamental method. Hal ini berarti jika koefisien $b$ bernilai positif $(+)$ maka dapat dikatakan terjadi pengaruh searah antara variabel independen dengan variabel terikat (dependent), setiap kenaikan nilai variabel independen akan mengakibatkan kenaikan variabel terikat (dependent). Demikian pula sebaliknya, bila koefisien nilai b bernilai negatif (-), hal ini menunjukkan adanya pengaruh negatif dimana kenaikan nilai variabel independen akan mengakibatkan penurunan nilai variabel terikat (dependent).

Pengujian regresi ini dilakukan untuk mengetahui kemampuan variabel-variabel independen maupun bersama-sama dalam menjelaskan return saham perusahaan. Hasil pengujian tersebut akan memberikan dasar bagi penerimaan atau penolakan hipotesis penelitian. Untuk menguji signifikan model, digunakan pendekatan ANOVA (F-Test) dan untuk menguji signifikasi koefisien regresi setiap variabel independen digunakan t-test. Sedangkan alat yang digunakan untuk menguji signifikasi model tersebut, penulis menggunakan SPSS 17.

\section{Hasil Penelitian dan Pembahasan}

Berdasarkan hasil analisis deskripsi statistic di bawah ini ditampilkan karakteristik sampel yang digunakan di dalam penelitian ini meliputi : jumlah sampel $(\mathrm{N})$, rata-rata sampel (mean), nilai maksimum, nilai minimum serta standar deviasi untuk masing-masing variabel. Variabel dalam penelitian ini adalah Price to Book Value, Earning Per Share, Debt to Equity Ratio, Suku Bunga dan Inflasi. Earning Per Share (EPS) merupakan rasio antara laba bersih yang diperoleh dengan jumlah saham yang beredar. Rata-rata EPS perbankan tahun 20072012 adalah 136.4663 dengan standar deviasi sebesar 179.48056, nilai EPS terendah adalah 1.00 dan nilai tertinggi adalah 778.93. Debt to Equity Ratio (DER) adalah rasio perbandingan total hutang terhadap modal sendiri. Rata-rata DER 9.0779 dengan standar deviasi sebesar 2.77897, nilai DER terendah adalah sebesar 3.75 dan nilai tertinggi adalah 16.86 . Tingkat suku bunga atau interest rate merupakan rasio pengembalian sejumlah investasi sebagai bentuk imbalan yang diberikan investor, besarnya tingkat suku bunga bervariatif sesuai dengan kemampuan debitur dalam memberikan 
tingkat pengembalian kepada kreditur. Ratarata suku bunga 7.4351 dengan standar deviasi sebesar 1.21759, nilai suku bunga terendah adalah sebesar 5.75 dan nilai tertinggi adalah 9.50. Inflasi adalah suatu keadaan dalam perekonomian dimana terjadi kenaikan hargaharga secara umum atau turunnya nilai mata uang yang beredar. Rata-rata inflasi adalah 6.7077 dangan standar deviasi 2.57386, nilai inflasi terendah adalah sebesar 2.41 dan nilai tertinggi adalah 12.14. sedangkan Price to
Book Value merupakan perbandingan nilai pasar saham dengan nilai bukunya. Dari Ratarata $\mathrm{PBV}$ adalah 1.5515 dengan standar deviasi sebesar 0.76367, nilai terendah PBV adalah 0.32 dan nilai tertinggi adalah 3.53. Pengujian asumsi klasik yang dilakukan pada penelitian ini meliputi : Uji Normalitas, Analisis Uji Statistik, Uji Multikolinieritas, Uji Heterokedastisitas, Uji Autokorelasi. Hasil pengujian hipotesis sebagaimana tampak pada table berikut.

Tabel 1

Hasil Pengujian Hipotesis

\begin{tabular}{|c|c|c|c|c|c|c|c|c|}
\hline & \multirow{2}{*}{ Model } & \multirow{2}{*}{$\begin{array}{c}\text { Unstandardized } \\
\text { Coefficients B }\end{array}$} & \multirow{2}{*}{ Std. Error } & \multirow{2}{*}{$\begin{array}{c}\text { Standardized } \\
\text { Coefficients Beta }\end{array}$} & \multirow{2}{*}{$\mathbf{t}$} & \multirow{2}{*}{ Sig. } & \multicolumn{2}{|c|}{$\begin{array}{c}\text { Collienarity } \\
\text { Statistics }\end{array}$} \\
\hline & & & & & & & Tolerance & VIF \\
\hline \multirow[t]{5}{*}{1} & (Constant) & .883 & .370 & & 2.386 & .019 & & \\
\hline & EPS & .003 & .000 & .622 & 9.706 & .000 & .950 & 1.053 \\
\hline & DER & -.041 & .017 & -.150 & -2.383 & .019 & .984 & 1.016 \\
\hline & SUKU BUNGA & .187 & .040 & .298 & 4.669 & .000 & .955 & 1.047 \\
\hline & INFLASI & -.106 & .019 & -.357 & -5.637 & .000 & .974 & 1.026 \\
\hline
\end{tabular}

a. Dependent Variable : PVB

Sumber : Data Bursa Efek Indonesia yang diolah

Hipotesis pertama menyatakan bahwa earning per share (EPS) berpengaruh positif dan signifikan terhadap price to book value (PBV). Hal ini menunjukkan bahwa besarnya earning per share (EPS) pada perbankan berpengaruh signifikan terhadap price to book value (PBV). Earning Per Share yang tinggi menandakan bahwa perusahaan mampu memberikan laba dan tingkat kesejahteraan yang lebih baik pada pemegang saham, sehingga kepercayaan investor untuk menginvestasikan suatu saham meningkat, permintaan akan saham meningkat dan harga saham juga cenderung bergerak naik. Dampak akhirnya adalah Price to Book Value juga meningkat. Sebaliknya EPS yang rendah menandakan bahwa perusahaan telah gagal memberikan kemanfaatan sebagaimana yang diharapkan oleh pemegang saham. Hasil penelitian ini mendukung hasil penelitian Yogi Permana dan Tito Perdana Putra (2007) yang menyatakan bahwa EPS memiliki hubungan yang positifdan berpengaruh signifikan terhadap PBV. Hal ini juga sejalan dengan pendapat dari Robert Ang (1997) yang menyatakan bahwa keuntungan perusahaan yang semakin meningkat memberikan tanda bahwa kekuatan operasional dan keuangan perusahaan semakin membaik, sehingga memberikan pengaruh positif terhadap ekuitas.

Hipotesis kedua menyatakan bahwa debt to equity ratio (DER), berpengaruh negatif dan signifikan terhadap price to book value (PBV). Hal ini menunjukkan bahwa besarnya debt to equity ratio (DER) pada perbankan berpengaruh signifikan terhadap price to book value (PBV). Semakin tinggi tingkat leverage akan semakin tinggi resiko perusahaan, yang pada akhirnya akan menurunkan harga saham. Turunnya harga saham dapat mengakibatkan turunnya price to book value (PBV). Hasil penelitian ini mendukung penelitian Putra (2007), yang menyatakan bahwa debt to equity 
ratio berpengaruh negatif dan signifikan terhadap price to book value perusahaan. Makin tinggi tingkat leverage akan semakin tinggi resiko perusahaan yang pada akhirnya akan menurunkan harga saham.

Hipotesis ketiga menyatakan bahwa suku bunga berpengaruh positif dan signifikan terhadap price to book value (PBV). Hal ini menunjukkan bahwa besarnya suku bunga pada perbankan berpengaruh signifikan terhadap price to book value (PBV). Mudji dan Mudjilah (2003), penelitiannya berjudul peranan profitabilitas, suku bunga, inflasi dan nilai tukar dalam mempengaruhi pasar modal di indonesia selama krisis ekonomi. Hasil dari penelitian membuktikan bahwa profitabilitas, suku bunga, inflasi dan nilai tukar secara bersama-sama mempengaruhi price to book value secara signifikan. Penelitian ini berbeda dengan penelitian yang dilakukan Yogi permana menemukan bahwa suku bunga dan inflasi tidak berpengaruh terhadap price to book value.

Hipotesis keempat menyatakan bahwa inflasi berpengaruh negatif dan signifikan terhadap price to book value (PBV) pada perbankan. Hal ini menunjukkan bahwa besarnya inflasi pada perbankan berpengaruh signifikan terhadap price to book value (PBV). Pada kondisi inflasi yang tinggi maka harga barang-barang cenderung untuk meningkat. Peningkatan harga barang-barang dan bahan baku akan membuat biaya produksi menjadi tinggi sehingga akan berpengaruh pada penurunan jumlah permintaan yang berakibat pada penurunan penjualan, hal ini mengurangi pendapatan yang diperoleh investor dari investasinya sehingga investor cenderung ingin menjual atau melepaskan suatu saham, dan harga saham cenderung bergerak turun, yang berdampak pada penurunan price to book value. Hasil penelitian ini sejalan dengan dengan penelitian yang dilakukan oleh Iswadi dan Yunina (2006) dalam penelitiannya menyimpulkan bahwa tingkat inflasi mempunyai pengaruh negatif terhadap harga saham.

\section{Simpulan, Keterbatasan dan Implikasi Hasil Penelitian}

Penelitian ini mencoba untuk menjawab tujuan penelitian yaitu membuktikan dan menjelaskan seberapa kuat pengaruh Earning Per Share, Debt to Equity Ratio, suku bunga dan Inflasi terhadap Price to Book Value pada Perbankan yang terdaftar di Bursa Efek Indonesia selama periode 2007 sampai dengan 2012. Hasil pengujian hipotesis dengan menggunakan analisis regresi linear berganda dengan empat variable independen (Earning Per Share, Debt to Equity Ratio, suku bunga dan Inflasi) dan satu variable dependen Price to Book Value (PBV) menunjukkan bahwa :

1. Hasil Pengujian Simultan (Uji F) menunjukkan bahwa Earning Per Share (EPS), Debt to Equity Ratio (DER), suku bunga dan Inflasi menunjukkan pengaruh secara signifikan dan simultan terhadap price to book value (PBV) pada perbankan yang terdaftar di Bursa Efek Indonesia (BEI) periode 2007-2012. Hasil penelitian ini mendukung penelitian Eva (2010), yang berjudul Analisis Pengaruh DER. DPR, ROE dan SIZE terhadap PBV Perusahaan Manufaktur Yang Listing Di BEI Periode 2005-2007.

2. Earning Per Share (EPS) berpengaruh positif dan signifikan terhadap price to book value (PBV) pada perbankan. Hal ini menunjukkan bahwa Earning Per Share yang tinggi menandakan perbankan mampu memberikan laba dan tingkat kesejahteraan yang lebih baik pada pemegang saham, sehingga kepercayaan investor untuk menginvestasikan suatu saham meningkat. Hasil penelitian ini sejalan dengan hasil penelitian Yogi Permana dan Tito Perdana Putra (2007) yang menyatakan bahwa EPS memiliki hubungan yang positif dan berpengaruh signifikan terhadap PBV.

3. Debt to Equity Ratio (DER) berpengaruh negatif dan signifikan terhadap price to book value (PBV) pada perbankan Hal ini menunjukkan bahwa semakin tinggi tingkat leverage akan semakin tinggi resiko perbankan, yang pada akhirnya akan menurunkan harga saham. Turunnya harga saham dapat mengakibatkan turunnya price to book value. Hasil penelitian ini mendukung penelitian Putra (2007), yang menyatakan bahwa debt to equity ratio (DER) berpengaruh negatif dan signifikan terhadap price to book value (PBV) perusahaan.

4. Suku Bunga berpengaruh positif dan signifikan terhadap price to book value (PBV) pada perbankan. Hasil penelitian ini medukung penelitian Isnaniyah Febritasari 
(2004), yang menyatakan bahwa tingkat suku bunga mempunyai pengaruh positif secara signifikan terhadap harga saham.

5. Inflasi berpengaruh negatif dan signifikan terhadap price to book value (PBV) pada perbankan. Hal ini menunjukkan bahwa inflasi yang tinggi maka harga barangbarang cenderung untuk meningkat. sehingga akan berpengaruh pada penurunan jumlah permintaan yang berakibat pada penurunan penjualan, sehingga investor cenderung ingin menjual suatu saham, dan harga saham cenderung bergerak turun, yang berdampak pada penurunan price to book value. Hasil penelitian ini sejalan dengan penelitian yang dilakukan yang dilakukan oleh Iswadi dan Yunina (2006) dalam penelitiannya menyimpulkan bahwa tingkat inflasi mempunyai pengaruh negatif terhadap harga saham.

Adapun keterbatasan-keterbatasan yang terdapat dalam penelitian ini yaitu sebagai berikut:

1. Penelitian ini memiliki sampel yang sedikit akibat adanya persyaratan sampel harus dipenuhi untuk mendapatkan hasil analisis yang lebih baik.

2. Keterbatasan dalam pengambilan variabel yang digunakan dalam penelitian ini khususnya untuk variabel akuntansi hanya diwakili earning per share dan debt to equity ratio. Masih banyak variabel akuntansi lainnya yang dapat memberikan pengaruh terhadap price to book value.

3. Periode penelitian yang pendek menyebabkan jumlah pengamatan yang dilakukan tidak terlalu banyak.

4. Jenis perusahaan yang digunakan dalam sampel penelitian ini hanya terbatas pada perbankan, sehingga belum dapat mencerminkan hasil dari perusahaan yang terdaftar di Bursa Efek Indonesia.

Berkaitan dengan keterbatasan diatas maka penelitian yang akan datang terdapat di harapkan memperhatikan hal-hal penting yaitu penelitian mendatang perlu menambah variabel fundamental lainnya dan juga variabel teknikal, seperti variabel ekonomi makro dan lainnya sebagai variabel independen, karena sangat dimungkinkan variabel lain yang tidak dimasukkan dalam penelitian ini berpengaruh kuat terhadap price to book value (PBV).

\section{Daftar Pustaka}

Ang R., (1997). Buku Pintar Pasar Modal Indonesia, Mediasof :Jakarta

Ariadi, 2009, Analisis Pengaruh Laba Akuntansi, Arus Kas operasi, Arus Kas Pendanaan, Debt to Equity Ratio, Curent Ratio dan Koefisien Variasi terhadap Harga Saham, Tesis.

Arifin, A. (2004). Membaca Saham, Edisi Pertama, Cetakan Kedua. CV. Andi Offset: Yogyakarta.

Brigham, Eugene $\mathrm{F}$ and Houston, Joel F. (2011). Essential of Financial Management, Terjemahan, Salmeba Empat : Jakarta.

Eva E.H., 2010, Analisis Pengaruh DER, DPR, ROE dan Size terhadap PBV Perusahaan Manufaktur yang Listing di BEI Periode 2005-2007, Tesis.

Hidayati. E.E., (2010). Analisis Pengaruh DER, DPR, ROE dan SIZE Terhadap PBV Perusahaan Manufaktur Yang Listing Di BEI Periode 2005-2007. Tesis S2 Dipublikasikan, Universitas Diponogoro, Semarang.

Harahap, S.S., (2004). Analisa Kritis Atas Laporan Keuangan. PT. Raja Grafindo : Jakarta

Herman B.S.,(2003). Pengaruh Perbedaan Laju Inflasi dan Suku Bunga pada Nilai Tukar Rupiah Terhadap Dolar Amerika, dalam kurun waktu Januari 2000- Desember 2002. Majalah Ekonomi, tahun XIII, No.3 : Desember.

Husnan, S., (2003). Dasar-dasar Teori Portopolio dan Analisis Sekuritas. Edisi Keempat, Yogyakarta :UPP AMP YKPN.

Imam G., (2009) Aplikasi Analisis Multivariate dengan SPSS,BP Undip : Semarang.

Iswadi dan Yunina, 2006, Pengaruh Laba Akuntansi, Financial Leverage dan Tingkat Inflasi Terhadap Harga Saham, Jurnal E-Mabis FE-Unimal, Volume 7, Nomor 1, Januari 2006, No.3-Oktober-2005.

Jogiyanto, H., (1998). Teori Portofolio dan Analisis Investasi. Edisi 2. BPFE: Yogyakarta

Manurung J., Manurung, A.H. (2005). Ekonomi Keuangan \& Kebijakan Moneter. Salemba Empat: Jakarta.

Marfuatun, S., I Indarti (2012), Pengaruh Earning Per Share, Debt to Equity Ratio, dan Return On Equity terhadap Harga Saham Perusahaan LQ-45 di Bursa Efek Indonesia, Vol. 14 No.1 hal. 63-73. 
Miller, M dan Rock. K., (1985). Dividend Policy Under Asymetric Information. Journal of Finance

Mudji U. dan Mudjilah R., (2003). "Peranan Profitabilitas, Suku Bunga, Inflasi Dan Nilai Tukar Dalam Mempengaruhi Pasar Modal Indonesia Selama Krisis Ekonomi”, Jurnal Manajemen \& Kewirausahaan. Vol. 5, No.2, September 2003: 123-131

Wirawati N.G.P 2008, Pengaruh Faktor Fundamental Perusahaan Terhadap Price to Book Value Dalam Penilaian Saham Di Bursa Efek Jakarta Dalam Kondisi Krisis Moneter, Buletin Studi Ekonomi Volume 13 Nomor 1 Tahun 2008.

Putra T. P., 2007, Pengaruh Kinerja Keuangan Dan Beta Saham Terhadap Price to Book Value (Studi pada Perusahaan Real Estate dan Property yang Listed di BEI 2004-2006)

Purwanto dan Haryanto A., 2004, "Pengaruh Perkembangan Informasi Rasio Laporan Keuangan Terhadap Fluktuasi Harga Saham dan Tingkat Keuntungan Saham", Jurnal Akuntansi \& Auditing, Vol. 1, No.1, Hal. 17-33.

Ratih, D.S., (2006). Saham dan Obligasi, Edisi Pertama, Andi Offset: Yogyakarta.

Ross Stephen, Westerfield and Jordan, (2010) Fundamentals of Corporate Finance, Alternate Edition, Ninth, McGraw-Hill, U,S.

Safitri A.L., 2013., Pengaruh Earning per Share, Price Earning Ratio, Return on Asset, Debt to Equity Ratio dan Market Value Added Terhadap Harga Saham Dalam Kelompok Jakarta Islamic Index. Management Analysis Journal, Vol.2 No.2

Sartono, A.R. (2001). Manajemen Keuangan (Teori dan Aplikasi), Edisi Empat :Yogyakarta.

Sugiyono, (2010). Metode Penelitian Bisnis, Alfabeta :Bandung.

Wardjono, 2010, Analisis Faktor-Faktor Yang Mempengaruhi Price to Book Value dan Implikasinya pada Return Saham (Studi Kasus pada Perusahaan Manufaktur yang terdaftar di BEI), Dinamika Keuangan dan Perbankan, Mei 2010 Vol.2 No.1. 